\title{
Economia com justiça, solidariedade $e$ generosidade (Dt 14:22-15:23)
}

\author{
An economy with justice, solidarity and generosity
}

(Dt 14:22-15:23)

Júlio Paulo Tavares Mantovani Zabatiero ${ }^{a}$

\section{Resumo}

Este artigo é uma exegese sócio-crítica de Deuteronômio 14:22-15:23, uma seção do chamado Código Deuteronômico, que trata especificamente das normas para a estruturação econômica da vida social. A seção propõe uma estruturação da economia baseada na ação libertadora e pactual de YHWH, construída a partir de uma releitura crítica de tradições mesopotâmicas (assírias e babilônicas) de estruturação e restauração da ordem econômica. A seção é composta de cinco normas, organizadas de forma quiástica, as quais estabelecem um tipo de economia baseada na lógica da dádiva, com vistas a tornar concreta na vida social os princípios da justiça, solidariedade e generosidade entre os membros do povo de Deus. Podese comparar esta proposta deuteronômica com o projeto de economia solidária desenvolvido por Paul Singer e outros.

Palavras-chave: Dons. Paulo. Ministério. Carismas. Corpo de Cristo.

\section{Abstract}

The article consists of a socio-critical exegesis of Deuteronomy 14:22-15:23, a section of the so-called Deuteronomic Code in the book of Deuteronomy. The Section thematizes the economic dimension of the social life, setting up five norms to the structuring of that dimension. The economic structure presented is based on the concept of the liberating action of $\mathrm{YHWH}$, and it is developed literarily as a critical reading of similar traditions in Mesopotamia. The section is composed by fiver norms articulated as chiastic parallelism, establishing a kind of economic relations based on the logic of the gift, to make up an economic structure displaying the principles of justice, solidarity, and generosity.

\footnotetext{
a Faculdade de Teologia da IPI do Brasil (FATIPI), São Paulo, SP, Brasil. Doutor em Teologia, e-mail: posgraduacao@fatipi.edu.br
} 
Keywords: Spiritual Gifts, Paul, Ministry, Body of Christ, Charismata.

\section{Introdução'}

A busca por justiça é uma das constantes da vida social ao longo da história humana. Uma das dimensões mais frequentes dessa busca é a concretização da justiça econômica, ainda uma esperança utópica diante das injustiças cada vez mais gritantes da fase atual do capitalismo neoliberal. Uma das propostas para a implantação de uma economia mais justa é a chamada economia solidária, baseada na disposição humana para repartir e não no desejo humano por acumular mais e mais bens. Na Escritura do antigo Israel, encontramos vários textos que descrevem o que poderia ser entendido como uma forma anciã de projeto de economia solidária. Dentre esses textos destaca-se, a meu ver, o de Deuteronômio 14,22-15,23 uma coleção de cinco leis econômico-teológicas que se configuram como um projeto de economia que visava a concretização da justiça de YHWH no cotidiano da sociedade israelita. Não devemos entender estas "leis" como um programa positivo a ser implementado pelo Estado, mas como um projeto político-teológico para animar a reflexão e a vida do povo judaíta que enfrentava a dominação assíria na segunda metade do século VIII a.C. Este artigo é uma interpretação sóciocrítica do texto deuteronômico em diálogo com a busca atual por justiça e solidariedade na economia e na sociedade brasileira.

\section{Texto: Tradução e Estrutura}

22 Empenha-te em dar o dízimo de todos os frutos de tuas sementes, que saem do campo ano após ano. 23 Comê-lo-ás diante de YHWH, teu Deus, no lugar que Ele escolher para moradia de seu nome: o dízimo de teus cereais, de teu mosto, de teu azeite, e os primogênitos de teu gado e de teu rebanho, a fim de que aprendas a temer $\mathrm{YHWH}$, teu Deus, todos os teus dias. 26 E lá comerás, diante de YHWH teu Deus, e te alegrarás, tu e tua casa, 27 e o levita

\footnotetext{
1 Este artigo é uma atualização e adaptação de seção da minha tese doutoral, defendida em 2000 na Faculdades EST, e não publicada.
} 
que mora em tua cidade, porque ele não tem porção nem herança em teu meio. 28 Ao final de três anos, trarás todo o dízimo de tuas colheitas nesse ano, e guardá-lo-ás em tua cidade, 29 e virão: o levita, que não tem porção nem herança teu meio, o imigrante, o órfão e a viúva - que vivem em tua cidade - e comerão e ficarão saciados, a fim de que te abençoe YHWH, teu Deus, em toda obra de tuas mãos, que fizeres.

15,1 Ao final de sete anos farás sh ${ }^{e}$ mitta. 2 Assim a farás: todo credor deverá abrir mão da cobrança do empréstimo. Aquele que emprestou ao seu próximo não cobrará o seu próximo, o seu irmão, pois foi proclamada a sh ${ }^{e}$ mitta perante YHWH. 3 Poderás cobrar do estrangeiro (não-residente) que estiver em teu meio, mas não cobrarás a dívida de teu irmão, 4 a fim de que não haja pobre em ti. 6 Então YHWH, teu Deus, te abençoará conforme te prometeu.

7 Quando houver, em teu meio, um pobre entre teus irmãos, em uma de tuas cidades, na tua terra dada por YHWH, teu Deus, não endurecerás o teu coração, nem fecharás a tua mão para o teu irmão pobre. 8 Esforça-te em abrir a tua mão e emprestar-lhe, conforme a necessidade dele. 9 Cuida que não haja pensamento maligno em teu coração, como este: "aproxima-se o sétimo ano, o ano da shemitta", e assim te tornes indisposto para com teu irmão pobre e nada lhe dês. Ele clamará contra ti a YHWH, e haverá em ti pecado. 10 Dá-lhe, e não te seja pesado fazê-lo. Por isso YHWH, teu Deus, te abençoará em toda tua obra e em todos os teus empreendimentos. 11 Ora, não deixará de haver pobres na terra, por isso eu te ordeno: empenha-te em abrir tua mão para teu irmão, teu pobre, e teu necessitado na tua terra.

12 Se te for vendido teu irmão, hebreu ou hebreia, servir-te-á por seis anos. No sétimo, deixá-lo-ás ir livre. $13 \mathrm{E}$ ao deixá-lo livre, não o despedirás de mãos vazias; 14 provê-o de teu rebanho, e de tua eira e de teu lagar; conforme te abençoou YHWH, teu Deus, darás a ele. 15 E lembra-te: foste escravo no Egito e YHWH, teu Deus, te resgatou. Por isso, hoje te dou este mandamento, para cumpri-lo. 16 Mas se ele te disser "não irei embora", porque ama a ti e à tua família, pois tem sido bom para ele; 17 então tomarás a sovela e lhe furarás a orelha contra a porta. Ele será, assim, teu escravo para sempre. Farás o mesmo à tua escrava. 18 Não te seja difícil libertá-lo, pois te serviu durante seis 
anos, sendo isso o equivalente ao salário de um trabalhador, e $\mathrm{YHWH}$, teu Deus, te abençoará em tudo o que fizeres.

19 Todo primogênito macho, nascido de teu gado ou de teu rebanho, consagrarás a YHWH, teu Deus. Não deixarás trabalhar o primogênito do teu gado e não tosquiarás o primogênito do teu rebanho. 20 Diante de YHWH, teu Deus, comê-lo-ás - ano após ano - no lugar que YHWH escolher, tu e tua família. 21 Mas se ele for defeituoso, manco ou cego, ou tiver qualquer outro sério defeito, não o sacrificarás a YHWH teu Deus. 22 Comê-lo-ás em tua cidade, juntos, o puro e o impuro, como comerias a gazela ou o cervo. 23 Todavia, não comerás o seu sangue; derramá-lo-ás, como água, sobre a terra.

Esta seção do Código Deuteronômico é organizada através de um interessante jogo espacial e temporal que forma um paralelismo quiástico:

A O Dízimo 14,22-29

B A sh ${ }^{e}$ mitta 15,1-6

C A Generosidade 15,7-11

B’ A Libertação 15,12-18

A' A Oferta do Primogênito 15,19-23

As normas da moldura ( $A$ e $A^{\prime}$ ) são cumpridas no espaço sagradolitúrgico (local único de adoração escolhido por YHWH) e seguem um ritmo temporal de um e três anos, as internas (B e B'; C) são cumpridas no espaço sagrado-cotidiano ("dentro dos portões", ou seja, na cidade) e seguem um ritmo temporal de um, seis e sete anos; reproduzindo assim o ritmo da criação divina - já marcada pela presença do pecado (o sagrado desordenado, necessitado de reordenação). Os anos terceiro e sexto do ciclo são delimitados discursivamente pela solidariedade generosa e recebem as leis econômicas peculiares do Código Deuteronômico: o dízimo trienal e a lei do empréstimo no sexto ano (que instaura a obrigação de dar ao necessitado que, muito provavelmente, não iria pagar naquele ano, e seria perdoado no ano seguinte). Os anos primeiro e sétimo são delimitados discursivamente pela dádiva: no primeiro, dízimo e primogênitos ofertados a Deus e consumidos em celebração festiva por todo o povo no espaço sagrado-litúrgico; no sétimo, perdão de dívida e libertação dos endividados escravizados, no espaço sagrado-cotidiano. 
Constata-se, assim, o equivalente histórico do ritmo sabático da criação - desordenado pelo pecado, porém. O sétimo ano, o do descanso divino é também o do descanso do povo: os que receberam a bênção (sagrado ordenado) a partilham com os que não a receberam (sagrado desordenado) - assim, os doadores descansam do trabalho, abençoando (como YHWH) e os recebedores descansam do sofrimento, recebendo (como a criação). Os seis anos anteriores são os anos da criação e do pecado, a sociedade é permanentemente re-criada em justiça após o descanso sabático abençoador, mas se contamina pela carência econômica e pela injustiça social que a desestruturam, gerando segmentação hierárquica - a ser minimizada no terceiro e sexto anos, e eliminada no sétimo. É, então, um tempo cíclico, mas não estático. É um tempo controlado por Deus que o delimita, mas atravessado pelas pessoas, que profanam o tempo divino com o pecado da injustiça, e trazem também sobre si mesmas os obstáculos à bênção divina. Mas é um tempo dinâmico também na sua qualidade salvífica, pois é o tempo determinado pela libertação do Egito, que deve ser reatualizada míticohistoricamente dentro de cada ciclo de sete anos, mediante as ofertas a Deus partilhadas com o necessitado, e mediante a ação econômica decisivamente libertadora dos que têm em relação aos que não-têm.

A sociedade que vive esse ritmo partilha do espaço sagrado nas suas distinções entre espaço litúrgico (da celebração solidária) e espaço cotidiano (do perigo, da bênção e da solidariedade), entretanto, as fronteiras entre os espaços litúrgico e cotidiano são redesenhadas pela invasão do litúrgico no cotidiano: no terceiro ano mediante a entrega dos dízimos nos portões, e no sétimo, pela proclamação da remissão diante de YHWH. Assim, vê-se que o regime da dádiva deuteronômico é de fato um fenômeno social total2, que visava determinar toda a vida de Judá sob a égide da bênção recebida e retribuída através da adoração e da solidariedade. Percebe-se aqui, também, que assim como o espaço, o tempo deuteronômico é um tempo sagrado demarcado pelo tempo litúrgico e pelo tempo cotidiano, ao qual se aplicam as

\footnotetext{
2 "Todos esses fenômenos são ao mesmo tempo jurídicos, econômicos, religiosos e mesmo estéticos, morfológicos, etc." (MAUSS, M. "Ensaio sobre a dádiva. Forma e razão da troca nas sociedades arcaicas". In: MAUSS, M. Sociologia e Antropologia. vol. II. São Paulo: E.P.U./EDUSP, 1974, p. 179.)
} 
mesmas características e qualidades aplicadas ao espaço - dado que estava oculto nas leis anteriores, mas também a elas aplicado.

Como consequência da solidariedade, na terra dada por YHWH a existência de pobres não deveria ser uma realidade permanente, porque ela é o espaço sagrado da bênção, e bênção é sucesso e prosperidade, vida digna e abundante. Teologia deuteronômica da terra pode ser lida sob a ótica do regime da dádiva: a terra é dada por $\mathrm{YHWH}$, como herança ao seu povo, e nela o povo é ricamente abençoado, para que cumpra integralmente a lei do Senhor (cf. Dt 4 in passim; 6,18-25; 7,12s; 8,1.7-11; 11,8-22). A terra é, ao mesmo tempo, a bênção de YHWH para o seu povo e o lugar onde YHWH irá abençoar o seu povo. "Não é preciso que Israel esteja preocupado pela terra. lahweh é quem se preocupa por ela em nome de Israel. Ele jamais retira dela os seus olhos poderosos, através do ciclo completo da vida e da nutrição" (BRUEGEMANN, 1987, p. 78), ao invés de preocupação, a preservação da terra seria alcançada com a adoração, e a prática de solidariedade e justiça, expressões do caráter do mesmo Deus que doara a terra ao seu povo.

\section{Gratidão e solidariedade no espaço sagrado litúrgico}

As leis do dízimo e do sacrifício dos primogênitos (bem como os demais sacrifícios e oferendas litúrgicas) podem ser melhor entendidas à luz da teoria de Marcel Mauss sobre a dádiva. Para ele, a dádiva é um fato social total, que, como tal, instaura um regime:

A vida material e moral e a troca funciona aqui sob forma desinteressada e obrigatória ao mesmo tempo. Além disso, esta obrigação exprime-se de maneira mítica, imaginária ou, se se quiser, simbólica e coletiva: assume o aspecto de interesse ligado às coisas trocadas. Estas nunca são completamente desligadas dos que as trocam: a comunhão e a aliança que eles estabelecem são coletivamente indissolúveis (MAUSS, 1974, p. 92).

É possível perceber os traços gerais do regime da dádiva na sociedade judaica conforme descrita no Código Deuteronômico. Os autores do Código afirmam repetidas vezes que YHWH é o libertador (dá liberdade e terra para viver) e abençoador (dá as condições para viver bem) de Seu povo, por isso, também se apresenta como soberano exigente (demanda a retribuição da 
dádiva a ele, na forma dos dízimos, ofertas e sacrifícios), mas fiel a seu caráter libertador e abençoador, a retribuição não é só a Ele, mas também aos necessitados do povo (carentes da dádiva divina da bênção). Desse modo, a dádiva divina recebida é retribuída simultaneamente a Ele e ao necessitado no culto sacrificial. De fato, a novidade deuteronômica é a de que a retribuição a YHWH é, na prática, retribuição/dádiva à família e ao necessitado, na medida em que é ofertada para ser consumida pelos ofertantes, sua casa e seus pobres. Se a dádiva divina não for retribuída, com a dádiva ao necessitado, o regime é rompido - o sagrado é ameaçado, a fronteira entre natureza e cultura é quebrada, pois a "cultura" nega a generosidade da "natureza". 0 dízimo trienal, entregue diretamente ao necessitado, é um caso especial que ressalta a natureza do regime judaíta da dádiva, na perspectiva deuteronômica: a solidariedade para com o dependente economicamente é o símbolo mais eficaz do regime da dádiva, na medida em que o solidário, ao entregar o dízimo fora do espaço sagrado-litúrgico, e dentro do sagradocotidiano, realiza a ação abençoadora do próprio YHWH no espaço próprio da Sua atividade libertadora e abençoadora. Notemos os temas mais importantes das perícopes.

A lei do dízimo tem no verso 22a seu enunciado fundamental: de toda a produção agrícola anual (frase similar ocorre em Êx 23,10; Lv 19,25b; 23,29; 25,3.7; Dt 14,28; 16,15; 22,9; 26,12), a décima parte deve ser separada do uso cotidiano e - conforme a explicação do enunciado em 23ab. 26b. 27, e a motivação da mesma em $23 \mathrm{C}$ - consagrada ao uso litúrgico. Os dízimos, porém, não serão destinados ao sacerdócio, mas, consumidos em um festivo banquete que celebre a generosidade de $\mathrm{YHWH}$ que abençoa seu povo com os frutos da terra. Indica, assim, a atitude do adorador que reconhece o senhorio de YHWH sobre a terra e os seus frutos, através da consagração de uma parte da colheita - interditando-a ao uso cotidiano. Trata-se, portanto, de uma refeição litúrgica, da família agraciada pelos produtos do campo, no espaço sagrado cotidiano - dádiva de YHWH, e não de qualquer outro deus - e do levita que não tem terra, portanto, não recebe a bênção direta de YHWH na forma de produtos do solo. Nessa refeição, no espaço sagrado litúrgico, os participantes se alegram pela bênção, e, na alegria cúltica do receber, crescem em solidariedade ao retribuir. 
A lei apresenta regulamentação para uma circunstância específica. No caso do ofertante morar longe do lugar escolhido por $\mathrm{YHWH}$, em função da bênção de YHWH, o dízimo poderá ser vendido, ao invés de levado até o lugar escolhido. Com a prata auferida pela venda do dízimo, o ofertante compraria o equivalente ao que houvera vendido, a fim de cumprir a determinação da lei: realizar a refeição diante de YHWH, com a sua família e os levitas. Desde uma perspectiva sociológica, esta injunção nos permite deduzir que a economia judaica, no período já contava com um significativo componente financeiro (embora não com "moeda" cunhada), de modo a permitir o comércio de produtos agrícolas. Desde uma perspectiva antropológica-cultural, o dízimo foi "ressacralizado", ou seja, em comparação com a perspectiva sacerdotal (textualizada em Levítico e Números), o produto separado para o dízimo não possui santidade inerente, só se torna interditado para o uso cotidiano após a entrega no lugar escolhido. Semelhantemente, em perspectiva econômica, não é um meio de sustento do sacerdócio profissional do Templo, nem um tributo ao Estado monárquico.

O que é peculiar ao Código Deuteronômico, no tocante ao dízimo, é a regulamentação do dízimo trienal que, como vimos, faz o espaço litúrgico invadir o cotidiano, de modo a abençoar os necessitados e economicamente dependentes da sociedade. É possível precisar a condição social dos favorecidos por esta lei? A questão dos levitas foi abordada na discussão da lei do altar único. Os imigrantes não precisam ser apenas pessoas de diferente origem étnica. Podem ser pessoas deslocadas de seu local de origem, seja por razões pessoais ou por razões derivadas de conflitos sociais, e que passam a viver na dependência dos moradores da nova localidade onde habitam, uma vez que não possuem terra para garantir a sua subsistência. Órfãos e viúvas também recaem na categoria de pessoas sem-terra, pela falta do homem “chefe da família” e titular da propriedade. A preocupação deuteronômica é procedente, dado o aumento do número de tais pessoas após as guerras com os assírios, e possui uma forte base teológica, ao afirmar que "YHWH é o Deus que faz justiça ao órfão e à viúva" $(10,18)$ - o que representa uma crítica à ideologia monárquica - tanto a do davidismo (v. SI 72, por exemplo), quanto a de outros países do Antigo Oriente, incluindo a Assíria, que afirmava a condição do rei como protetor dos economicamente dependentes. Para o 
Deuteronômio, todas as pessoas que têm "assegurada a sua base econômica" são responsáveis pela defesa dos economicamente dependentes. A base para esta ideia é sua noção de "povo de Deus", como um povo de irmãos.

A motivação para o cumprimento desta injunção, encontra-se no verso 29 e remete ao regime da dádiva na perspectiva deuteronômica. Y. Muffs tece apropriados comentários sobre a "psicologia" da dádiva no pensamento judaico. Particularmente no tocante ao Deuteronômio, afirma:

A ideia de que Deus irá recompensar o doador que se alegra - isto é, aquele que dá de acordo com sua habilidade - mediante o aumento de sua propriedade e, implicitamente, assegurando-o de que sua habilidade para dar crescerá ainda mais, motivou o seguinte comentário: 'Dá-lhe (a pessoa necessitada) prontamente, e não te entristeça ao fazê-lo' (Dt 15,10), de modo que não se possa dizer: 'hoje estou dando, de modo a destruir minhas propriedades, e amanhã eu dependerei deles'. Por isso se diz: por causa disto (o Senhor teu Deus te abençoará) (Dt $15,10)^{\prime}$. A Torah não isenta o israelita de suas responsabilidades legais, mesmo que sofra por causa de sua observância. Aqui é importante reassegurar o doador de que ele não sofrerá, a fim de que dê livre e voluntariamente (MUFFS, 1982, p. 180-181).

A lei dos primogênitos tem o enunciado fundamental aparecendo em 15,19b e as explicações sobre seu cumprimento em 19a.20-22. No verso 23 um adendo de caráter genérico, a respeito do sangue dos animais utilizados na refeição (cf. 12,16.23-24). A exigência é a de consagração de todos os primogênitos machos do gado bovino e ovino. Eles devem ser entregues a YHWH como reconhecimento de Sua soberania e generosidade como doador da vida. Esses animais consagrados a YHWH não poderão ser utilizados no trabalho, nem ser tosquiados (19b). Como animais consagrados, são interditados para o uso no espaço cotidiano, não podem redundar em lucro ou benefício econômico para seus proprietários. Provavelmente esta injunção se tornou necessária em virtude da definição da oferta do primogênito apenas uma vez por ano, e não ao oitavo dia de vida (cf. Êx 22,30). De modo similar ao dízimo, os primogênitos ofertados a YHWH devem ser consumidos em uma refeição cúltica e festiva da família no local escolhido por YHWH. Nessa refeição cúltica, porém, só poderão ser utilizados os animais puros, sem mancha. Os animais impuros devem ser retidos nas cidades e utilizados como alimento - também para eles vale a injunção de 19b, são animais interditados 
para o uso cotidiano, podendo apenas servir como alimento, a fim de não romper a fronteira entra a natureza e a cultura, nem implantar caos na ordem sagrada. Seguindo as instruções do capítulo 12, da refeição feita com os animais impuros podem participar todas as pessoas, mesmo as que não poderiam participar, por alguma impureza, das reuniões cúlticas; configurando, aqui, um caso peculiar de invasão do espaço cotidiano pelo litúrgico. O uso do primogênito impuro como refeição deve seguir as mesmas regras para o abate e utilização dos animais não englobados pela lei dos primogênitos (cf. Dt 12, 15-25).

Indicamos, acima, a interdiscursividade polêmica destas leis contrárias aos regulamentos cúlticos que faziam das ofertas litúrgicas um meio de sustento da religião oficial (templo e sacerdócio a serviço da monarquia). Há que se perguntar pela interdiscursividade contratual, quais eram os discursos críticos da liturgia oficial com os quais o movimento deuteronômico poderia ter dialogado? Os candidatos mais prováveis são os textos da crítica profética ao culto, no VIII séc. a.C. Em Amós 4,4Ss, encontramos referência ao uso das ofertas como meio de tributação religiosa: "Vinde a Betel e transgredi, a Gilgal, e multiplicai as vossas transgressões; e de manhã trazei vossos sacrifícios, ao terceiro dia os vossos dízimos; e oferecei sacrifícios de louvores do que é levedado, e apregoai ofertas voluntárias, publicai-as; porque disso gostais, ó filhos de Israel, disse o Senhor Deus.” Em Amós, transgressão tem o sentido de crime, não só um pecado "contra Deus", mas o pecado contra o povo de Deus; Betel e Gilgal eram santuários oficiais do reino do Norte, colocados sob o juízo do profeta, pois o culto neles prestado não só era idolátrico, como também legitimador da injustiça social (Am 5,4ss; 5,21ss; 7,1017). Crítica semelhante encontramos em Isaías (1,10-17), que também vincula o culto à legitimação da injustiça social em Jerusalém e Judá: “De que me serve a mim a multidão de vossos sacrifícios? Diz o Senhor. Estou farto dos holocaustos de carneiros e da gordura de animais cevados, e não me agrado do sangue de novilhos, nem de cordeiros, nem de bodes [...] Não continueis a trazer oferta vãs [...] Pelo que, quando estendeis as vossas mãos, escondo de vós os meus olhos; sim, quando multiplicais as vossas orações, não as ouço, porque as vossas mãos estão cheias de sangue." A junção estrutural destas leis sobre ofertas cúlticas e a justiça econômica sugere que o projeto 
deuteronômico visava apresentar uma alternativa plausível à junção de culto e injustiça social que, nos profetas citados, era denunciada, mas não se oferecia uma alternativa concreta.

\section{Solidariedade e gratidão no espaço sagrado cotidiano}

A lei da remissão de dívidas tem no verso 1 o seu enunciado fundamental. "No final de sete anos" é a forma literal da indicação temporal da lei. Não é necessário entender literalmente a expressão, a não ser que queira indicar que as dívidas somente eram cobradas no final do ano. "Farás remissão". Esta tradução procura destacar o seu sentido através da desmetaforização. O substantivo (Dt 15,1.2.9; 31,10) deriva do verbo Jmv, literalmente "deixar cair", “deixar ir embora”. A lei exige o pleno perdão das dívidas no sétimo ano, de modo que a cada ciclo de sete anos a economia possa ser reorganizada, eliminando-se as distorções que foram surgindo no período.

O princípio detrás da lei não é ‘a cada homem o que lhe é devido conforme sua importância', mas, sim, 'a cada homem o que lhe é devido conforme sua necessidade'. Isto significava que na lei se fazia todo esforço necessário para proteger o pobre, o fraco, o sem-defesa (WRIGHT, 1954, in loco).

Enquanto a lei do descanso da terra (cf. Êx 23,10-11), na qual a legislação deuteronômica aparentemente se baseia, é tipicamente aplicável a uma realidade essencialmente agrícola com baixa segmentação socioeconômica, a lei deuteronômica já se aplica a uma realidade econômica com relativamente elevada taxa de segmentação socioeconômica, demandando as alterações realizadas, que caracterizam uma relação de interdiscursividade mostrada e contratual.

A explicação do enunciado fundamental da lei está nos versos 2-3. A estrutura quiástica da seção enfatiza a motivação para o cumprimento da lei: "pois foi proclamada a remissão perante YHWH" — dotando de sacralidade litúrgica um ato econômico, realizado no espaço cotidiano. O perdão das dívidas tem força jurídica e teológica. A proclamação garante a força jurídica e a legitimidade da lei (cf. Lv 23,2.4.27; 25,9: Is 61,1.2; Jr 34,8). A expressão hw"hyl; (perante YHWH) ocorre em Dt 12,7.12.18 (2x); 14,23.26; 15,20 e 16,11.15.16 (2x, sem a preposição $\left.I^{e}\right)$. É um termo técnico da legislação deuteronômica relativo 
à adoração a YHWH e já o estudamos na lei do altar único. Sua presença aqui destaca o vínculo indissolúvel, para o discurso deuteronômico, entre adoração a YHWH e solidariedade para com os empobrecidos.

O sujeito que deve cumprir a lei, o credor, é aquele que detém/retém, em sua mão, o empréstimo, provavelmente na forma de um “certificado" de dívida, que representa a quantia (em espécie ou em dinheiro) que ele emprestou. Desse “certificado" deverá abrir mão, ou seja, deverá deixá-lo cair no chão, como sinal concreto do perdão da dívida, de sua desistência de cobrála. O beneficiário da lei é todo devedor que reside no país e partilha da sorte dos seus moradores, do povo de YHWH. Os termos usados são: próximo e irmão. Ambos são comuns na lei deuteronômica, mas só aqui ocorrem juntos, em uma construção apositiva. Normalmente na legislação deuteronômica “irmão" é o compatriota, o membro da família de YHWH; embora também seja usado para se referir a irmãos de sangue. O próximo é o amigo, o vizinho, uma pessoa que mantém relações de amizade com outra. Provavelmente o uso de “irmão", aqui, tenha sido motivado pela exclusão do "estrangeiro" do grupo de beneficiários da lei. O estrangeiro, no verso 3, não é o imigrante, mas aquele que está de passagem, provavelmente um comerciante, e que não partilha do dia-a-dia do povo de YHWH. De forma similar à sua presença como beneficiário do dízimo trienal, o “imigrante” não é excluído do perdão das dívidas. A lei não se aplica somente a "judaítas", mas a todos os que tomaram empréstimo para garantir sua sobrevivência e a manutenção de sua família.

As relações interdiscursivas aqui são de cunho (a) contratual, em relação à lei do descanso sabático do Código da Aliança, e (b) polêmico, em relação às leis de perdão de dívida nos países mesopotâmicos, mas com a apropriação de elementos dos discursos polemizados, como forma de fortalecer retoricamente a lei. Dos decretos mesopotâmicos, apropria-se do aspecto propriamente econômico: o do perdão dos débitos, com vistas a reorganizar a economia, mas polemiza com as questões ligadas ao sujeito da lei (que na Mesopotâmia é o rei), seus destinatários (que são escolhidos pelo rei em função das necessidades econômicas do Império) e sua época (na Mesopotâmia, somente são publicados os decretos de perdão quando o rei entende que deva fazê-lo). Segundo o livro de Jeremias, o rei Sedecias, sob o domínio babilônico, editou um tal decreto de perdão, na perspectiva 
mesopotâmica (Jr 34,8-22) — um indício de que o Código não possuía força legal vinculante.

A lei do empréstimo no sexto ano também é uma peculiaridade do Código Deuteronômio. Apresenta o seu enunciado fundamental na forma de uma lei casuística, e a designação dos seus beneficiários é fortemente carregada de termos preferidos pelo movimento deuteronômico: em teu meio, pobre, teus irmãos, teus portões, na tua terra que YHWH teu Deus te dá, teu irmão pobre. O pobre é aquele que não possui os meios necessários para garantir seu sustento e o sustento de sua família. É a pessoa que precisa da ajuda do próximo, depende do socorro de seu irmão. Diante do irmão pobre, o israelita não deve “endurecer o seu coração". Esta metáfora retrata a obstinação daquele que possui bens, sua teimosia em retê-los, sem desejar ajudar o necessitado. Em paralelismo sinônimo com esta frase verbal, encontramos "nem fecharás a tua mão", também uma expressão idiomática que expressa teimosia, obstinação, falta de solidariedade. O uso desta expressão aqui é bastante apropriado, em contraste com a lei anterior, que exigia do credor que "abrisse a sua mão". É significativo que o enunciado fundamental da lei seja expresso em termos negativos e tematize a atitude do destinatário da lei.

Na explicação do enunciado fundamental da lei, em estrutura quiástica, a ênfase passa para o tom positivo. O que a lei tem em vista é que as pessoas que têm bens, "abram a sua mão" para as que não têm, para os empobrecidos. Duas vezes (v. 8, 11) é dada a ordem para abrir a mão, mediante o uso da construção forte do imperativo - com evidente força retórica (infinitivo mais verbo na forma finita). O significado concreto dessa metáfora é encontrado no verso 8b: abrir a mão e emprestar ao pobre tudo aquilo de que ele necessita. O verbo “emprestar" é usado apenas nesta lei, v. 8, no acréscimo posterior, v. 6 , e em Dt 24,10 na lei sobre os penhores. O substantivo derivado ocorre apenas em Hc 2,6 em uma imprecação contra "o que se carrega de penhores". No verso 10, ao invés de "emprestar", a lei usa o imperativo "dar liberalmente". Isto, em conexão com o uso de um termo incomum para o empréstimo comercial, destaca o caráter solidário do "empréstimo" aqui legislado. O que está em jogo é a necessidade do irmão, e não a possibilidade de ganhar dinheiro em um negócio. Pelo contrário, a possibilidade de prejuízo 
é patente, e tanto mais quanto mais $\mathrm{YHWH}$ seja imitado pelos abençoados por Ele.

A ênfase no aspecto motivacional é percebida no uso de três expressões idiomáticas concernentes aos sentimentos e atitudes humanos, que possuem uma força retórica muito grande. A primeira, literalmente, é "cuida que não haja em teu coração uma palavra de Belial". A origem e a etimologia de "Belial" são incertas. A palavra é usada 27 vezes no Antigo Testamento, das quais 15 estão na literatura deuteronômico-deuteronomística. Em contextos jurídicos, refere-se às pessoas que violam a lei e colocam em perigo a harmonia social. $O$ uso deste termo, aqui em Dt 15,9 indica que a falta de solidariedade para com o empobrecido é uma violação da harmonia e da fraternidade que devem imperar entre os membros do povo de Deus. A segunda expressão é: “e seja maligno o teu olho para com teu irmão”. A expressão é comum e amplamente disseminada em todo o Antigo Oriente. “O ‘olho maligno’ (ou “mau-olhado”) era uma expressão de inveja, avareza, desprezo e malícia, e que era injuriosa para os outros, para o próprio ‘usuário’ e para o seu relacionamento com Deus [...] Para a comunidade definida e vinculada pela aliança, o olho maligno simbolizava desvio moral e social inaceitável. Evitá-lo, por outro lado, reforçava o apoio mútuo e a coesão social, e promovia os valores e ideais da justiça pactual" (ELLIOT, 1991, p. 159). A terceira expressão, "e não seja mal o teu coração", indica o desprazer diante de algum ato, ou diante de alguma circunstância. Neste caso, a recomendação é a de que a generosidade não seja motivo de tristeza, não seja um fardo para a pessoa que socorre o seu próximo em necessidade.

O centro estrutural destes versos é ocupado por uma expressão única em todo o Antigo Testamento: "E ele clamará contra ti a YHWH, e haverá em ti pecado". A ideia de que YHWH é o Deus que ouve o clamor dos empobrecidos e oprimidos é recorrente no Antigo Testamento, e é um dos temas preferidos da teologia do êxodo e das liturgias de lamento. O seu uso aqui não é uma novidade. O novo é a afirmação de que a retenção do empréstimo é "pecado". A ideia de que o "pecado" é algo que se pode carregar ocorre, por exemplo, em Lv 19,17; 22,9 e Nm 18,32. Carregar o pecado implica, também, em ser culpado por esse pecado. Em nosso contexto, a falta de solidariedade para com o empobrecido gera o clamor a YHWH. Em resposta ao clamor do pobre, 
YHWH considera "pecadores" aqueles que, tendo meios para tanto, não socorrem o pobre. Ao invés do pobre ser considerado "maldito", é o detentor de bens que pode ser considerado sob a maldição de $\mathrm{YHWH}$, se não usar os seus bens para socorrer o seu próximo.

Esta lei ocupa o centro da seção sob estudo. Apresenta o cerne da proposta de reorganização econômica de Judá. A existência de pobres na terra é um fato, sinal da não plenitude da bênção divina na terra. Para lidar com essa situação, a única resposta possível é a generosa solidariedade dos abençoados por YHWH. Aqueles que têm bens, devem ter um coração generoso, olhos bondosos e mãos abertas para socorrer os que estão carentes. Os empobrecidos não são amaldiçoados por YHWH, mas vítimas de circunstâncias que não têm controle. Serão amaldiçoados, sim, os que têm bens, se não os colocarem a serviço dos necessitados. A lógica do regime da dádiva, no projeto deuteronômico, não é a da eficiência econômica. Não é, principalmente, a lógica tributária acumulativa do Estado ou do Templo, nem a lógica tributária imperialista da Assíria. É, pelo contrário, a lógica da solidariedade. Onde houver uma pessoa necessitada, aqueles que têm condições devem socorrê-la, uma vez que o sucesso no trabalho e a prosperidade econômica são fruto da bênção de YHWH, o soberano de Judá, e não devem ter como fim o enriquecimento pessoal, mas a justiça social. Como vimos, acima, é bastante provável que esta perspectiva deuteronômica tenha sido construída em diálogo com a crítica profética à injustiça social legitimada pelo culto a YHWH. Uma sociedade regulada pela "eficiência" econômica pode mascarar o fato de que é uma sociedade maligna. Para a lei deuteronômica, os abençoados devem agir como o próprio YHWH agiu em favor de seu povo, oprimido no Egito, semterra e sem futuro: tendo toda a terra, abriu mão de parte dela para beneficiar os israelitas.

A lei do empréstimo — no sexto ano — é seguida pela da libertação dos escravizados, após seis anos de serviço. No verso 12 encontramos o enunciado fundamental da lei, em forma casuística. Determina que, no caso do empobrecido, homem ou mulher, ser vendido ao seu credor, somente poderá servi-lo como escravo durante seis anos. Não se podia conceber que um israelita pudesse ser escravizado, contra a sua vontade, por toda a vida. Cumprido o período previsto pela lei, deveria ser libertado. A venda à 
escravidão representava, principal, mas não exclusivamente, o pagamento de uma dívida impossível de ser quitada doutra maneira. Nos v. 13-14 temos a explicação do modo de cumprimento da lei. A peculiaridade deuteronômica é a injunção para que o(a) escravo(a) libertado(a) receba bens3 suficientes para poder recomeçar a sua vida econômica. De nada adiantaria a manumissão se o beneficiado por ela não pudesse se restabelecer, logo voltando à condição de devedor, economicamente dependente, e passível de se tornar novamente escravo. Novamente, vemos a lógica do regime deuteronômico da dádiva em operação. Os abençoados por YHWH não podem deixar de abençoar o seu próximo, especialmente o empobrecido e necessitado.

A motivação teológica para a manumissão dos escravos hebreus é a memória do êxodo. O dono de escravos de hoje é o escravo de ontem. Se o destinatário da lei é possuidor de escravos isso se deve, em última análise, à libertação da qual ele mesmo foi beneficiário no passado de seu povo. De fato, toda a lei deuteronômica é fundamentada no ato libertador de YHWH. A manumissão dos hebreus escravizados pelos egípcios é a fonte da aliança e da vida do povo. Consequentemente, o povo da aliança deve ser fiel às suas origens, e não se tornar, para com o seu próximo, como os egípcios. Não devem se tornar opressores de seus próprios irmãos. O uso do motivo teológico do Êxodo é recorrente no Deuteronômio (cf. 5:15; 16,12; 24,18.22), e possui papel importante na polêmica discursiva contra o imperialismo assírio. A lei é concluída, no verso 18 , com mais uma cláusula motivacional, desta vez, de caráter econômico: o trabalho do escravo durante os seis anos foi suficiente para pagar qualquer dívida que ele tenha contraído para com seu senhor. Este deve libertá-lo, pois não seria justo explorar o trabalho de seu irmão mais tempo.

Nos versos 16 e 17 encontra-se a possibilidade de que o(a) próprio(a) escravo(a) não queira ser beneficiado pela manumissão. Dado o enunciado da lei, a única circunstância em que esse desejo poderia surgir seria o amor do(a) escravo(a) pelo seu senhor $(15,16)$. Esta cláusula de exceção sugere-nos que,

\footnotetext{
${ }^{3} \mathrm{O}$ verbo aqui utilizado só ocorre novamente no SI 73:6. Literalmente refere-se a um colar. Obviamente seu uso aqui é figurado, e pode ser uma reminiscência da tradição do êxodo, no tocante à provisão dos hebreus saídos do Egito com as riquezas dos egípcios, como compensação por sua servidão (Êx 12:35-36).
} 
para muitos, a servidão seria uma condição mais adequada de vida do que a liberdade, dadas as dificuldades para a estabilidade econômica, especialmente de pessoas sem-terra. Diferentemente de Êx 21,5s, a motivação para permanecer com o senhor não é o amor à família que seria perdida, e a cerimônia de perpétua servidão não seria realizada perante YHWH, como um ato cúltico, no espaço litúrgico, mas perante os demais cidadãos, como um ato familiar, no espaço cotidiano. O que está em jogo é a possibilidade de que as pessoas privadas de bens não permaneçam assim por toda a sua vida. Se o perdão das dívidas no sétimo ano do ciclo sabático possibilitava um rearranjo geral da economia, a manumissão do escravo contemplava aquelas pessoas que, mediante sua autovenda, se colocaram fora do alcance daquela lei. Para estes, também, o projeto deuteronômico oferecia uma solução: a manumissão com a "compensação" financeira, de modo que pudessem retomar sua atividade econômica com chances de sucesso. Afinal de contas, a bênção de YHWH também se endereçava a eles, mediante a solidariedade de seus credores. A lei da manumissão criava as condições para que aos "novos hebreus" fosse dado acesso a um "novo êxodo". Assim, aquele evento que criara o povo de Israel, poderia ser repetido em benefício de cada indivíduo que caísse na condição de "hebreu”. Deste modo, o regime da dádiva seria cumprido em sua totalidade, e a aliança de $\mathrm{YHWH}$ seria cumprida em benefício de todos os membros do povo, especialmente das vítimas de circunstâncias econômicas. Vê-se aqui a relação polêmica com os tratados assírios, que implementavam relações assimétricas de aliança, forjada não sob a dádiva da terra, mas sob a sua conquista, e mediante as quais os vassalos do soberano eram obrigados a sustentá-lo com o tributo e a corveia (para o exército e para obras) - instaurando-se assim um regime de dádiva não solidário, mas caracterizado pela ilusão do caráter doador do soberano, encobrindo, de fato, um regime de dívida.

\section{Conclusão}

O projeto deuteronômico de uma economia regida pela lógica da dádiva se contrapunha à lógica da dívida que regia a economia e a política dos impérios do antigo Oriente. Enquanto tal, sua proposta é relevante em nossos 
dias, não como um modelo legislativo a ser seguido, mas como uma fonte para a construção de uma teoria da justiça que contemple a dimensão econômica da vida humana em sociedade. A economia capitalista é baseada, como nos impérios antigos, em um regime de dívida, fundada na competitividade e acumulação e não na solidariedade e generosidade. A proposta deuteronômica de uma economia fundada no regime da dádiva oferece um contraponto radical à justificativa para a validade do neoliberalismo políticoeconômico, e nos ajuda a alimentar sonhos e utopias de construção de uma sociedade mais justa e digna para a sua população.

\section{Referências}

BRUEGEMANN, W. A Terra na Bíblia. Dom, Promessa, Desafio, Tentação. São Paulo: Paulinas, 1987.

ELLIOT, J. H. "The Evil Eye in the First Testament. The Ecology and Culture of a Pervasive Belief". In: JOBLING, D.; DAY, P. L.; SHEPARD, G. T. (eds.) The Bible and the Politics of Exegesis. Essays in honor of Norman K. Gottwald on his sixty-fifth birthday. Cleveland: Pilgrim Press, 1991. p. 147-159.

MAUSS, M. “Ensaio sobre a dádiva. Forma e razão da troca nas sociedades arcaicas". In: MAUSS, M. Sociologia e Antropologia. vol. II. São Paulo: E.P.U./EDUSP, 1974. p. 37-184.

WRIGHT, G. E. Deuteronomy. In: BUTTRICK, G. (ed.) The Interpreter's Bible. v. 2. Nashville: Abingdon Press, 1954. 